\title{
PSYCHE.
}

\section{ON THE PIGEON MITE, HYPODECTES FILIPPI.}

BY HENRY B. WARD, PH.D., LINCOLN, NEBR.

The November, I892, number of Insect Life contained a note by Prof. D. S. Kellicott on a mite found in the thymus of a pigeon; on the authority of Murray ('77) it is said to be Hypoderas columbae. Last spring while working in the zoological laboratory of Harvard University, I obtained specimens of this same form through the kindness of Dr. W. McM. Woodworth, who had found them some time previously in the loose peritracheal tissue of a pigeon. Study of the parasites and of the literature bearing upon the group revealed so many points of interest, especially concerning this stage in the life history, that it seems proper to present here an abstract of the work of previous investigators since the number of names under which this form has been described renders its study difficult. The apparent lack of information among American students as to its interesting and complicated life history is due also, no doubt, to the inaccessibility of most of the papers bearing upon the subject. Together with this review is given as complete a bibliography as it has been possible to prepare. For assistance in this I am indebted to Mr. A. D. Michael of London, Eng. and to Profes- sor J. A. Lintner of Albany, N. Y. Reference has been made in the bibliography to reviews, abstracts and translations of the original articles so far as known to the writer, but the list is probably not complete.

The first published account of this parasite seems to have been that of Montagu ('o8) whose description and figures leave no doubt as to the close relationship of the form he observed to that found in the pigeon, while at the same time the specific identity of the two forms must always remain uncertain on account of the incompleteness of his description. He named the form which he found in the gannet, Cellularia Bassoni.

Two Italian naturalists, Géne ('48) and Filippi ('6r), were the next to record observations on similar mites. Filippi made a new genus, Hypodectes, to include them and described five species parasitic in the areolar tissue of various birds, each species receiving a name from its host.*

In the same year Giebel ('6r), without knowledge of this last paper, published a posthumous article by Nitzsch

*His synopsis of these species together with their hosts is to be found in Mégnin ('79, p. 131). 
in which a number of species were figured and described under the name of Hypoderas, n. g. In a note some time later Giebel ('63) acknowledged the identity of Nitzsch's genus Hypoderas with Hypodectes Fil., which had been brought to his attention and which might justly claim priority. In this note Giebel criticizes the plan of Filippi in naming the species after the host since, as Nitzsch emphasizes, the same species may be found in more than one host and, on the other hand, the same host may harbor more than one species of the parasite.

Robertson ('66) published a short account of the discovery of a mite parasitic in the English pigeon, but he appears to have been entirely ignorant of the work of his predecessors, except Montagu, whom he quotes. He gives a short account of the anatomy of the mite, recognizes it as an imperfect form, remarks upon its evident relationship to the Sarcoptidae and announces his intention of pursuing the subject further, a purpose which seems never to have been fulfilled.

Gerstäcker ('67) makes a brief mention of Robertson's work and identifies this mite as a species of Hypodectes Fil.*

A full account of the anatomy and histology of Hypodectes columbae, $n$. $s p$. is to be found in Slosarsky ('77) . $\dagger$ In this paper, read before a congress of Russian naturalists at Warsaw in 1875 ,

\footnotetext{
* The species which Robertson examined is said by Mégnin ('79, p. 13r) to be the same as Filippi's Hypo. dectes nycticoracis.
}

† On the authority of Mégnin ('79). the author adds a new species to the genus Hypodectes Fil. $\mathrm{He}$ found no internal structure at all except the narrow muscle bands just under the cuticula by which the movements of the body and appendages are effected. Further than this the interior of the body consisted of a granular vesicular mass in which cell structure could not be demonstrated.*

To the researches of Mégnin is due the greater part of our knowledge of the life history of this form. In a series of papers ('73-'79) he established the larval nature of a number of mites without mouth-parts which had previously been regarded as distinct genera, and showed them to be merely abnormal (?) stages in the life history of other known species. With Ch. Robin (Robin et Mégnin '77) he investigated among others the form found in the pigeon and showed it to be an abnormal (adventitious or "hypopial" $\dagger$ ) nymph of Pterolichus falciger Mégnin.

\footnotetext{
* In sections cut last spring I was equally unable to find either nuclei or cell walls in this granular mass. Claparède ('68) has shown that the metamorphoses of the Acarina are not simply ecdyses, but that the body undergoes an extended hystolysis.
}

\footnotetext{
† Hypopial, adj. derived from Hypopus. Mégnin ('73, p. 492) says "The conclusions to be drawn from my observations is that the genera Hypopus, Homopus and Trichodactylus, and the numerous species which have been established as subdivisions of those genera, must be stricken from our zoölogical nomenclature. The word Hypopus may be retrined, but only as a common name serving to designate the curious cuirassed, heteromorphous and adventitious nymph of the Tyroglyphi whose office is the preservation and dissemination of the species to which it belongs." The name was afterwards used by the same author for similar nymphs in other families, $e, g$. Pterolichus (Robin et Mégnin, '77, p. 403).
} 
Later Mégnin alone ('79) published an extensive memoir on the mites of the cellular tissue of birds. Therein he reviews the work of many of his predecessors and adds to his own previous contributions a more extended account of this stage and of its relation to the life history. Mégnin had found in Lophyrus coronatus Vieill. not a single form but two, one of which he showed to be the male nymph of Pterolichus falciger; the other he was inclined to regard as the female nymph of the same species on account of its strong resemblance to the normal female. Mégnin explains the occurrence of these forms in the cellular tissue in the following way:

So long as the conditions of existence remain the same, the succession of stages in the life history of the mites is invariably egg, larva, normal nymph, male or female, and then the egg again. If, however, the conditions change, if the food or shelter necessary to life begin to disappear, the colony seems doomed to destruction. Certain species escape that fate, thanks to a curious biological phenomenon which we discovered and named adventitious or hypopial metamorphosis. This has been found to occur in four species of Tyroglyphus and in one of Pterolichus, $P$. falciger, a plumicolous sarcoptide of the pigeon. . . . When a pigeon invaded by a colony of these mites begins to pull out its feathers, the mites are deprived of shelter and of the secretions which serve them as food, the normal life cycle is arrested and the normal nymph instead of giving rise to a male or female increases in size and brings out of its skin a new form, fitted to a new mode of life. This form is worm-like and has been described and figured under the name of an adventious or hypopial nymph; it introduces itself into the follicles of the feathers, or even by the respiratory organs and reaches the cellular tissue, especially the peritracheal, which is very loose in birds. Here it lives and grows by absorption, for it has neither orifices nor internal organs, and returns to the surface only when the normal conditions are established.

Mégnin found a normal nymph of Pterolichus falciger enormously developed and in process of metamorphosis; it contained the larger hypopial nymph. As to the nature of the smaller form which is supposed to be the hypopial nymph of the female, he was not able to furnish any direct proof.

Trouessart et Mégnin ('85) in their revision of the group, have placed the adult, of which Hypodectes is the hypopial nymph, in a new genus, Falciger.

Murray ('77) refers to the form found in the pigeon under the generic name of Hypoderas; but his description and figures are entirely inadequate for identification.

In the United States this form has been reported several times. H. Garman ('84) was the first to record its occurrence. He described it under its proper name, and recognized its nym- 
phal character. Leidy ('9o) noted very briefly its occurrence in the blue heron.* Kellicott's note ('92) has already been referred to ; and to this list must be added its occurrence in the pigeon at Cambridge, Mass., as found by Woodworth. It will thus be seen to be widely distributed and will no doubt be found in most localities. It may be hoped that more extended observations will furnish further evidence on its life history.

This review should not be terminated without calling attention to a paper by Michael ('84) which, though it does not deal with the mite found in the pigeon, is of great interest from its bearing on the hypopial stage in other mites. The author first gives a very complete review of the literature on Hypopus and tabulates at the close of that part of his paper the eight different views as to what a Hypopus really is. His own experiments are then given and after showing their entire incompatibility with six of the diverse theories, he says (p. 379) : "My own opinion decidedly confirms Mégnin's view that the true Hypopus is a heteromorphous nymphal form of Tyroglyphus, and possibly of some allied, or other, genera." At the close of his paper (p. 389) Michael summarizes his conclusions thus: "It appears to me:

I. That the true Hypopi are not adult animals, but are a stage in a life history.

2. That they are heteromorphous

* There is no evidence, however, that this is the same species. nymphs of Tyroglyphus and some allied genera.

3. That it is not all individuals that become Hypopi, but only a few.

4. That the hypopial period takes the place of that between two ecdyses in the ordinary life history.

5. That, in those species which I have examined, the hypopial stage commences with the second nymphal ecdysis.

6. That the change to Hypopus is not caused by unfavorable circumstances, and is not any extraordinary or exceptional circumstance, but is a provision of nature for the distribution of the species occurring irrespective of adverse conditions.

7. 'That, in the present stage of our knowledge, we can no more say why one nymph becomes a Hypopus and another does not, than we can say why one ovum produces a male and another a female."

It will be seen from this that while observations and experiments of Michael serve to establish and fix with greater precision Mégnin's view as to the occurrence of such a stage, the conclusions of the two authors as to the cause of its occurrence are widely at variance. To be sure Michael's work does not touch the hypopial form found in the pigeon and it is difficult to see how the explanation he offers with evident probability for the other forms, i. e. "the distribution of the species irrespective of adverse conditions," could possibly apply to the case of a hypopial form which like that from the pigeon lives in an inactive 
state in the tissue of the body of a bird.

Note. Since the above was written a year ago, there have been further refere nces to similar parasites. I wish to call attention only to the parasite of the Goura, found by Dr. L. Karpalles,* which does not seem to have been identified by the finder. It is probably this genus.

University of Nebraska, Lincoln, Neb.

Mch. 1894.

\section{BIBLIOGRAPHY.}

Baraldi, Giov.

'75. Stato particolare di una ninfa d'Acaride, Hypodectes carpophagae, n. sp. Atti Soc. Tosc. sci. nat., tom. i, p. 87-103, I taf.

Claparède, Ed.

'68. Studien an Acariden. Zeitschr. für wiss. zool., bd. xviii, 4 , p. 445-546, taf. $\mathrm{xxx}-\mathrm{xl}$.

FilipPi, FilipPo DE.

'6r. Note zoologiche. I, Hypodectes, novo genere di Acaridi proprio degli ucelli. Archiv. zool. anat. e fissiol. (Genova) fasc. i, p. 54-60, tav. v.

GaRMAN, H.

'84. Pterolichus falciger, Mégnin, observed in the United States. Amer. nat., vol. xviii, p. 430-43I, I wood cut.

Gené, G.

'48. Brevi cenni su un acaridio del genere dei Sarcopti che vive sulla Strix flammea. Scritto postumo, Torino 1848.

Gerstäcker, A.

'67. Bericht über die wissenschaftlichen leistungen im gebiet der entomologie während des jahres 1865-66, ii. hälfte,

*Ver, zool.-bot. gesellsch. Wien, bd. xlii, p. 46-7.
Archiv für naturgeschichte, bd. xxxiii. theil 2, p. 305-533.

Giebel, C. G.

'6r. Die Milbenarten der gattung Hypoderas Nitzsch. Zeitschr. f. d. gesammt. naturw., bd. xviii, p. 438-444.

'63. Hypoderas Nitzsch. $=$ Hypodectes Filippi. Zeitschr.f. d. gesammt. naturw., bd. $x x i$, p. 79-80.

KellicotT, D. S.

'92. Hypoderas columbae. A note. Insect life, vol. v, no. 2, p. 77-78, I fig.

LEIDY, Jos.

'9o. Hypoderas in the Little Blue Heron. (Florida caerulea.) Proc. acad. nat. sci. Philad., r89o, p. 63.

MÉgNin, P.

'73. Sur la position zoologique et le rôle des Acariens parasites connus sous les noms d'Hypopus, Homopus et Trichodactylus., Comptes rendus., tom. lxxvii, p. 129-1 32 , p. 492-3. Translated in Ann. mag. nat. hist., ser. 4, vol. xii, p. 429-3o.

'74. Memoire sur les Hypopus (Dugés) Acariens parasites encore nommés Homopus Koch et Trichodactylus L. Dufour. Journ. anat. et physiol., tom. x, p. 225254.

'76. Note sur la faculté qu'ont certains Acariens, avec ou sans bouche, de vivre sans nourriture pendant des phases entière de leur existence, et même pendant toute leur vie. Comptes rendus, tom. Ixxxiii, p. 993-995. Translated in Ann. mag. nat. hist., ser. 4, vol. xix, p. 270-27I.

'79. Les Acariens parasites du tissu cellulaire et des reservoirs aériens chez les oiseaux. Journ. anat. et physiol., tom. xv, p. 123-r 53, pl. vii-viii.

Michael, A. D.

'84. The Hypopus question, or the life history of certain Acarina. Journ. Linn. soc. Lond., Zool., vol, xvii, p. 37I-394, pl. $\mathbf{x v}$.

Montagu, G.

'08. Observations on some peculiarities observable in the structure of the gannet; 
and an account of an insect discovered to inhabit the cellular membrane of that bird. Mem. Wernerian nat. hist. soc., vol. i, p. 176-193, pl. vii, figs. 1-3.

Murray, A.

'77. Economic eritomology, Aptera. Scribner, Welford, and Armstrong, N. Y.

Robertson, C.

'66. Note on an undescribed species of Acarus found in the pigeon, Columba livia. Quart. journ. micr. sc., n. s. vol. vi, p. 20I-203, 4 figs. Abstracted in Amer. nat., vol. iii, p. 389 .

Robin, Ch., ANd Mégnin, P.

'77. Mémoire sur les Sarcoptides plumicoles. Journ. anat. et physiol., tom. xiii, p.
209-248, pl, xi-xii, p. 391-429, pl. xxiixxv, p. 498-52I, pl. xxvi-xxix, p. 629-656, pl. xxxvi-xxxviii.

Slosarsky, A.

'77. On the anatomy and systematic position of Hypodectes columbae, n. sp. Warsaw, I877, I4 pp., I pl. (In the Russian language.)

Trouessart E.-L. et Mégnin, P.

'85. Les Sarcoptides plumicoles ou Analgésines. I. Les Ptéroliches. Journ. de microgr., tom. viii, p. 92-IOI, I50-157, 2 I I-2 I9, 257-266, 33 I-338, 380-385, 428436, 527-532, 572-579, tom. ix, p. 63-7o, I09-I17. Also published separately, Paris, A. Doin, 8o., 84 pp., i7 figs., 2 pl.

\section{NOTES ON SOME MELOIDS, OR BLISTER BEETLES, OF NEW MEXICO AND ARIZONA.}

BY C. H. TYLER TOWNSEND, KINGSTON, JAMAICA.

The blister beetles form quite an important and characteristic feature of the coleopterous fauna of the southwest. I remember that the only entomological specimens that I could find in the Museo nacional, in the City of Mexico, were a case of the different species of native blister beetles. The Mexican highlands are quite rich in these forms, and it would seem that the descendants of the Spaniards in Mexico take a natural public interest in the relatives of the Spanish fly. At any rate, this interest exists to the exclusion of all other insects, so far as the Mexican national museum is concerned.

New Mexico and Arizona belong to the same natural region as the highlands of Mexico, and the following notes on nineteen species of meloids collected in those territories will be of interest. The specimens from Grant County, N. Mex., were collected by Mr. W. J. Howard, in 1882 , and formed a part of a collection donated by Hon. W. G. Ritch, ex-secretary of the Territory, to the Historical society, at Santa Fé, N. Mex.

Cysteodemus wislizeni Lec.-Found singly crawling on sandy mesa to eastward of Las Cruces, toward Organ mountains, August 2o, and other dates. This is a very peculiar spherical shaped species, of a brilliant blue or purple color, with more or less of metallic reflections. Det. by Liebeck.

Megetra vittata Lec.-A very large number of this large, lubber-like, black 

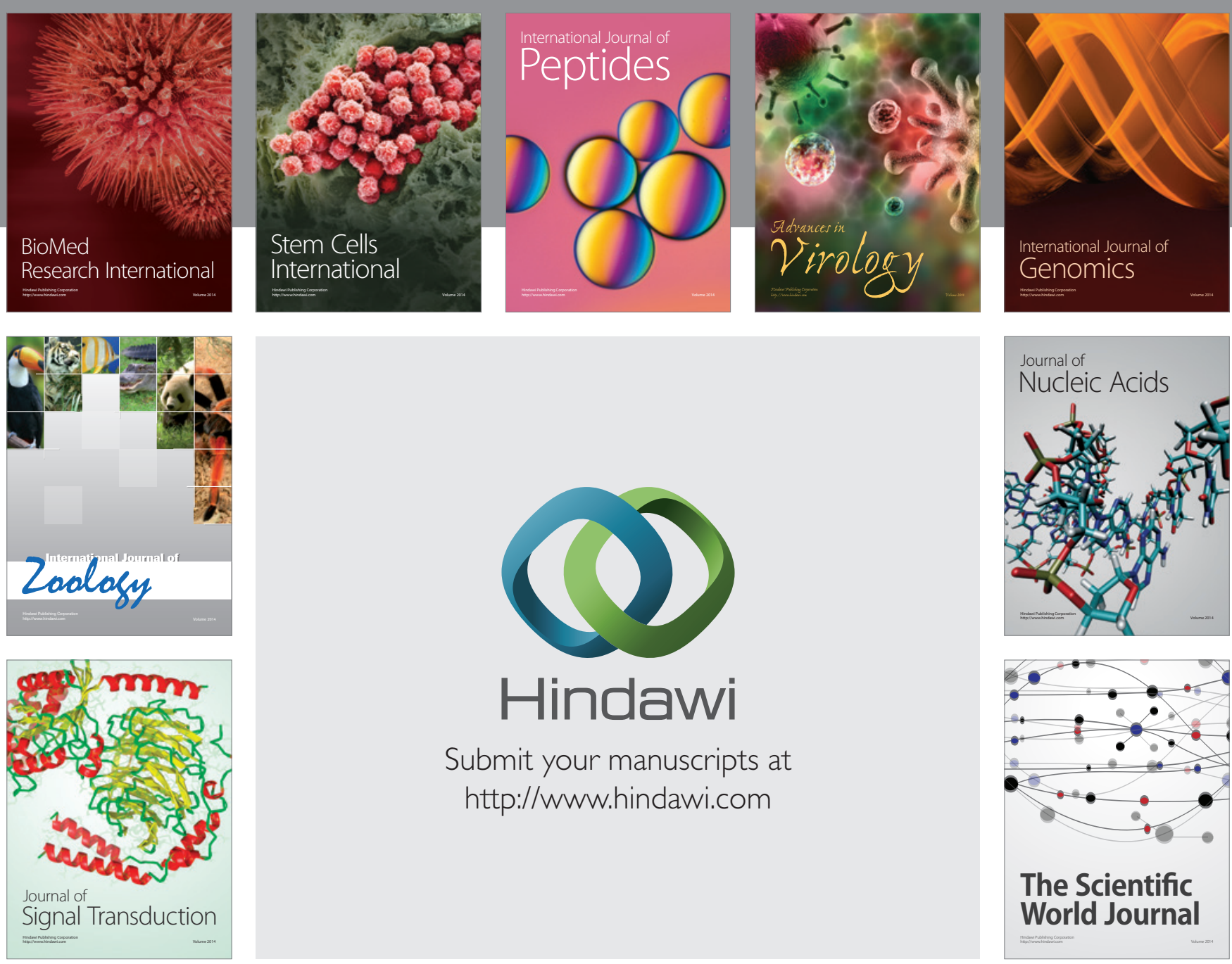

Submit your manuscripts at

http://www.hindawi.com
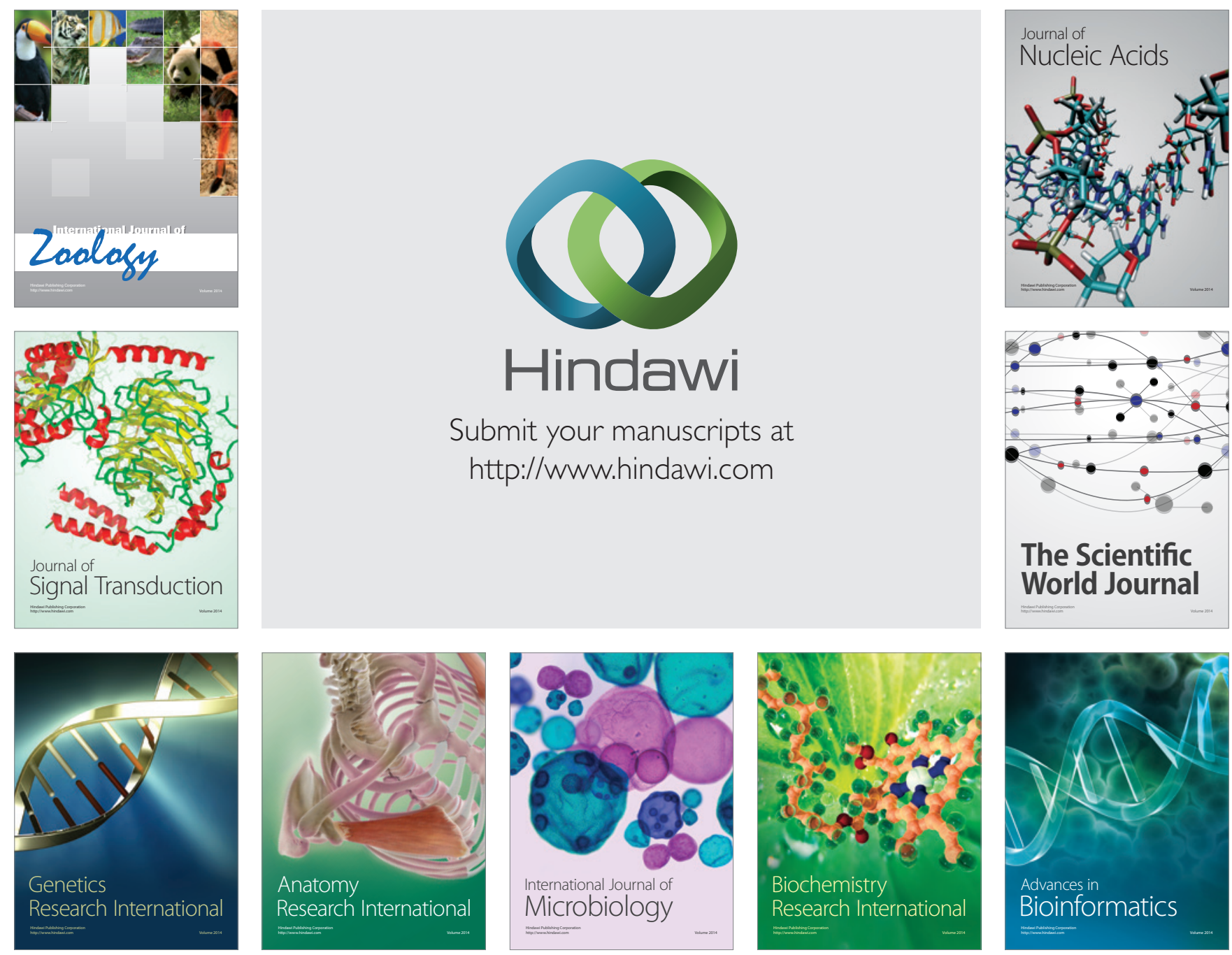

The Scientific World Journal
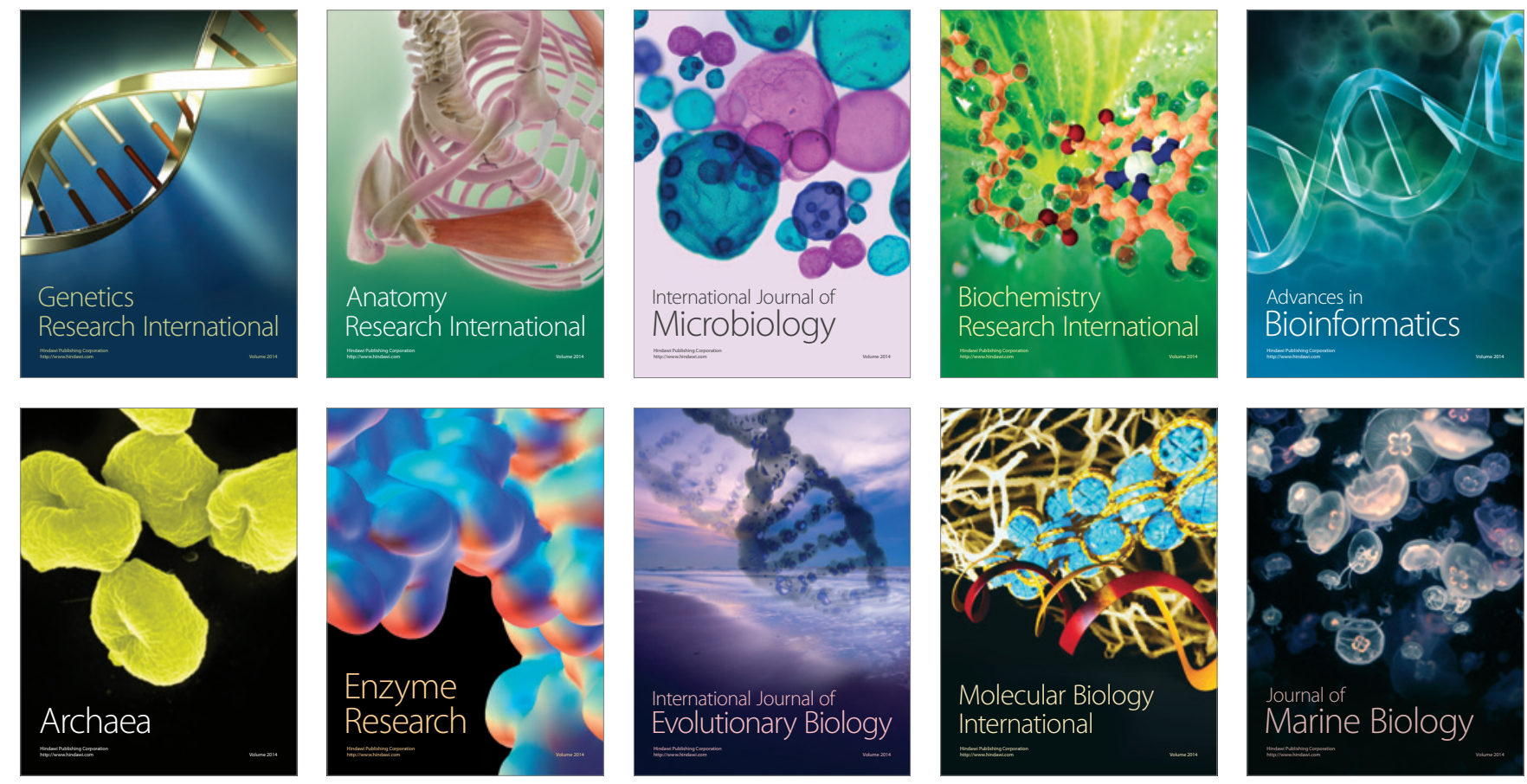